\author{
N. Lachashvili, N. Eradze \& K. Kereselidze
}

\title{
Systematic structure and florogenetic connections of dendroflora of Tbilisi area (South Caucasus)
}

\begin{abstract}
Lachashvili, N., Eradze, N. \& Kereselidze, K.: Systematic structure and florogenetic connections of dendroflora of Tbilisi area (South Caucasus). — Fl. Medit. 31: 135-152. 2021. — ISSN: 1120-4052 printed, 2240-4538 online.

Tbilisi area is located in the central part of South Caucasus at the intersection of various floristic centres. The aim of the article is to clarify composition of dendroflora of Tbilisi area, analysis it's systematic and chorological structure and establish florogenetic connections. 166 species of trees and shrubs, which belong to 74 genera and 41 families, were recorded. The leading families by the ratio of species are: 1 . Rosaceae $-32.6 \%$, 2. Salicaceae $-7.2 \%$, 3. Fabaceae 4.8\%, 4. Sapindaceae - 4.2\%, 5. Ulmaceae - 3.6\%, 6-7. Cupressaceae, Rhamnaceae - 3.0$3.0 \%$. Based on composition and proportion of chorotypes, several directions of florogenetic connection are identified: (1) Boreal, (2) Mediterranean, (3) South-West Asian, (4) Euxinean and (5) Hyrcanean. Dominance of local (Caucasian) species is sharply expressed (19.3\%). The composition and proportion of chorotypes points, that forming of dendroflora of Tbilisi area was going through the "struggle" of boreal and Ancient Mediterranean floristic centers. On the background of powerful competition, great number and different bioecological composition of local species emphasize originality of flora of Tbilisi area. We suppose that forming process of dendroflora of Tbilisi area was going on during a long period that not so small number of relict and endemic species speaks about.
\end{abstract}

Key words: trees, shrubs, floristic composition, chorotype, Ancient Mediterranean.

\section{Introduction}

Tbilisi area is located at the intersection of various floristic centers (Mediterranean, Boreal, South-West Asia, Turan) and represents distinctive "botanical junction" (Sakhokia 1961), which is clearly reflected in its biodiversity.

According to some researchers (Gagnidze \& Davitadze 2000), the study area belongs to the Ancient Mediterranean world. In particular, these authors discuss most part of the Tbilisi area within the range of Submediterranean and the endings of the Mtkvari-Araks lowland entering in Tbilisi area belong to the South-West Asia-Turan region. Some of the researchers (Takhtadjan 1978) attribute the largest part of the Tbilisi area to the boreal 
world, while the endings of Mtkvari-Araks lowland consider the Ancient Mediterranean (in particular to Turan province).

Tbilisi area are characterized by both floristic and ecosystem diversities. There are distributed approximately 1650 species of vascular plants (Makashvili 1952, 1953). Forests of foothill, lower and middle mountain belts, xeromesophilous and mesoxerophilous shrubberies, shrubberies of shibliak type and steppe are the main vegetation cover. They are presented by various modifications. Besides them, plant communities of desert-semidesert, xerophytic forests, tragacanthic shrubberies, meadow-steppe, meadows, saline meadow, floodplain forest and wetlands are distributed. Also there are rocks and scree-stones communities (Lachshvili \& al. 2013).

The role of trees and shrubs is especially prominent in the creation of natural landscapes (forests and shrubberies of different types) of Tbilisi area. In addition, trees and shrubs are spread in almost all ecosystems, including herbaceous ecosystems. Therefore, there is a great interest in the origins of dendroflora of Tbilisi area and its florogenetic connections.

The aim of our research was to clarify floristic composition of trees and shrubs of Tbilisi area, the systematic and chorological characterization of this dendroflora; based on their analysis establishing their florogenetic connections.

\section{Materials and methods}

Presented research is based on the article of Lachashvili \& al. (2017), in which conspectus of trees and shrubs of Tbilisi area are given. There are listed 177 species of trees and shrubs (included naturalized species) and for each species are indicated distribution area and habitat in Tbilisi area in this article. Systematic structure, composition of chorotypes and florogenetic connections are not discussed.

In recent years (2017-2020) floristic composition has been clarified and supplemented; according to new taxonomic data the name and volume of individual species was revised and clarified.

Chorotypes and their general areas correspond to the methods and principles of Ivanishvili (1973), Portenier (2000a, 2000b) and Gagnidze (2004). Phytogeographic zoning of Earth by Takhtadjan (1978) is taken into consideration. Brovich (1989) and Meusel \& Jager (1989) approaches and concepts are also taken into account. During the selection of chorotypes detailing was emphasized. Mono, double, triple, and in some occasions fourfold regional chorotypes are selected. The names of all those main botanic-geographic units, that the chorotype area contains, are used in the names of chorotypes. During determination of chorotype of the species and subspecies, the main attention is directed to the center of gravity of the species (subspecies) spread. In case the plant is ranked as subspecies (subsp.), the chorotype of the subspecies is given. By mentioned methodology, in the most chorotypes (where there a need and an opportunity were) lower-ranking units - chorological groups are separated. The selected chorotypes are apportioned in four major groups. They are: (1) boreal, (2) Ancient Mediterranean, (3) "connective" and (4) "widespread". Such attitude gave the opportunity to conduct more detailed analyzes (Lachashvili \& al. 2020).

The boarders of the Ancient Mediterranean and Boreal regions are defined according to Takhtajan (1978). Caucasus and accordingly, Caucasus endemics are discussed in the bounds of Caucasus eco-region (Solomon \& al. 2013). 
Names and authors of taxa are reconciled with international databases of plants [The plant list (2021), Euro+Med (2006+), IPNI (2021), GBIF.org (2021), Tropicos.org (2021)]. Only several "narrow" species are given according to Solomon \& al. (2013) and Davlianidze \& al. (2018).

\section{Description of study area}

Tbilisi area (Fig. 1) is located in the central part of South Caucasus. The territory covers part of Mtkvari River basin from vil. Dzegvi to the section between Ponichala and Rustavi. Endings of large geographical units of different origin and geological age are gathered in the area of Tbilisi, which greatly conditions complexity of the relief. In particular, Tbilisi area comprises the Saguramo-Ialno (Kukheti) Ridge, the eastern part (Skhaltba Ridge) of Kvernaki Ridge, the eastern endings of the Trialeti Ridge (Satskepela and Armazi, Mskhaldidi and Lisi, Mtatsminda, Narikala, Tabori, Kojori, Teleti ridges), the extreme end of the north-west and western parts of Iori plateau (Samgori, Vaziani, Tbilisi Sea and its vicinities), the extreme north-west end of the Mtkvari-Araxi lowland - Kvemo Kartli lowland, in particular, Ponichala and Kumisi-Tsalaskuri plaines. Hypsometrical amplitude of Tbilisi area is about from $350 \mathrm{~m}$ a.s.1. to $1875 \mathrm{~m}$ a.s.l. (Maruashvili 1964; Kavrishvili 1964; Ukleba 1968, 1974; Tatashidze 2000).

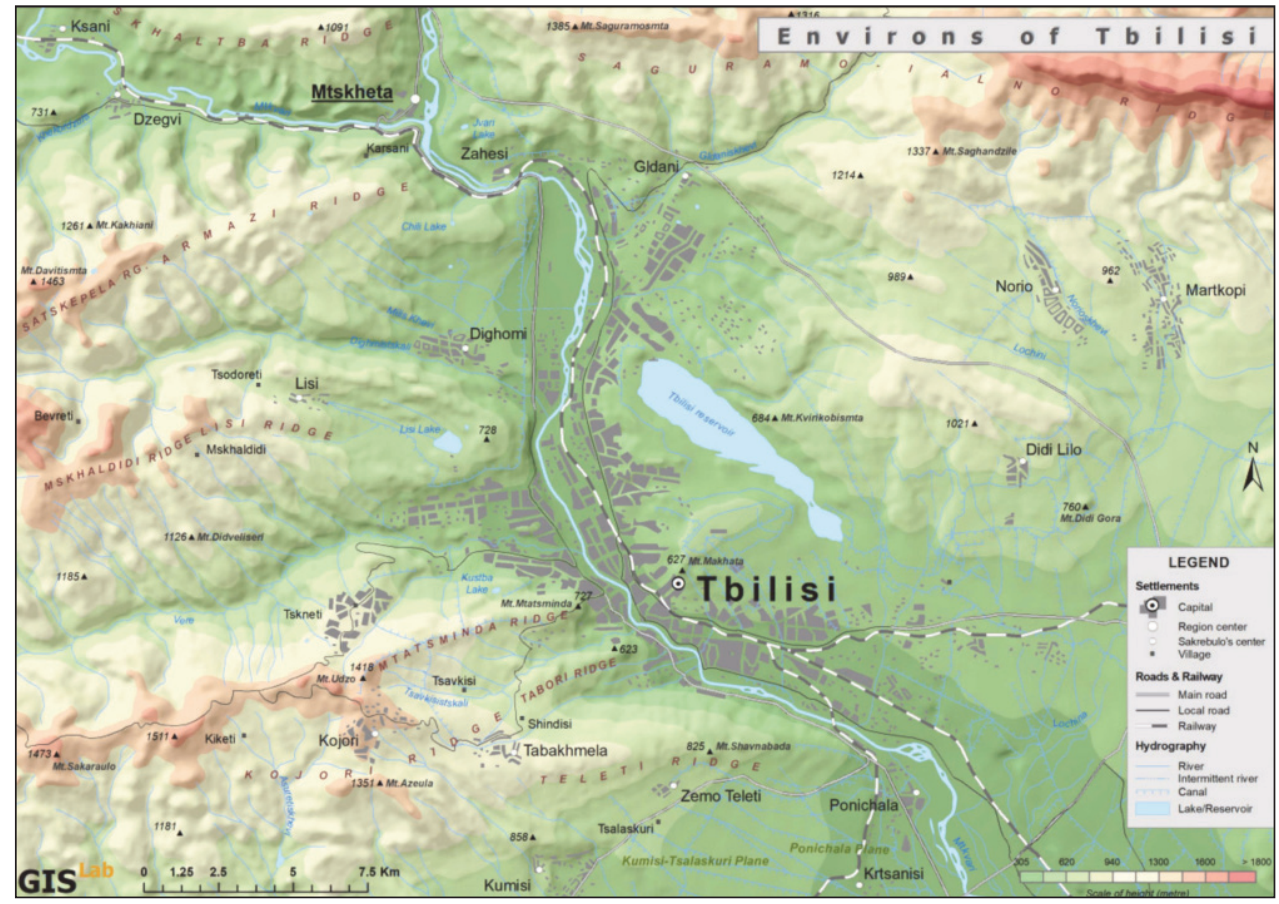

Fig. 1. Physical-geographic map of Tbilisi area. 
The area of Tbilisi is characterized by a transitional climate from semi-arid to humid. Two main climate zones are expressed (Kavrishvili 1964; Ukleba 1968): (1) The climate with insufficient humidity, dry and hot summer and mild but well expressed winter, (2) moderately humid climate with moderately warm summer and moderately cold snowy winter. The first zone of the climate contains almost whole left side of the Mtkvari River, Ponichala and Kumisi-Tsalaskuri plains and the river floodplain as well. The second climate zone covers Saguramo-Ialno Ridge and the mountainous part of the right side of Mtkvari River. In the first zone annual evaporation exceeds the sum of precipitation. The average annual temperature is within $12^{\circ}$, while the average annual atmospheric precipitation is from 380 to $530 \mathrm{~mm}$. In the most part of zone the dryness index equals to 2 . In the second zone the average annual precipitation $(550-780 \mathrm{~mm}$ ) increases with elevation, while the average annual temperature decreases (from $10.8^{\circ}$ to $7.4^{\circ}$ ). The humidity (precipitation-evaporation) ratio is 1 . The highest amount of precipitation is in the crest part of the Saguramo Ridge - approximately 1000-1200 mm. A transition from semihumid to humid climate is expressed in some parts of Tbilisi area.

Main soil types are grey-cinnamonic, cinnamonic and brown forest soils, which are presented by different modifications. On the terraces of rivers (especially along the Mtkvari River) there are alluvial soils developed. Besides them, there are rocky and scree-stony ecotypes and loamy and clayey-sandy badlands (Kavrishvili 1964; Ukleba 1968; Urushadze 1999, 2016; Tatashidze 2000).

\section{Results}

Systematical structure. - On the basis of own researches and literary data, 166 species of trees and shrubs are registered in Tbilisi area, which belong to 41 families and 74 genera.

Distribution of genera by families gives the following picture: with most of number of genera standout is Rosaceae - 12 genera (16.2\%). By 5 genera represented Fabaceae (6.8\%). 4 Families (Anacardiaceae, Oleaceae, Rhamnaceae and Ulmaceae) includes 3 genera each, 10 families - 2 and 25 families one genera each. Data demonstrates that most of the families (35 families) are presented by only 1-2 genera.

Number of species is distributed disproportionally in the families. 7 families standout by number of species (Table 1 ).

Table 1. Number of species by the leading families.

\begin{tabular}{|c|c|c|}
\hline Family & Number of Species & $\%$ \\
\hline 1. Rosaceae & 54 & 32.6 \\
\hline 2. Salicaceae & 12 & 7.2 \\
\hline 3. Fabaceae & 8 & 4.8 \\
\hline 4. Sapindaceae & 7 & 4.2 \\
\hline 5. Ulmaceae & 6 & 3.6 \\
\hline 6. Cupressaceae & 5 & 3.0 \\
\hline 7. Rhamnaceae & 5 & 3.0 \\
\hline Total & 97 & $58.4 \%$ \\
\hline
\end{tabular}


8-12 places are shared by 5 families: Celastraceae, Corylaceae, Fagaceae, Oleaceae and Viburnaceae. Any of them are presented by 4 species. 6 families (Anacardiaceae, Betulaceae, Caprifoliaceae, Cornaceae, Tamaricaceae and Thymelaeaceae) contain 3 species each, 8 families (Araliaceae, Berberidaceae, Elaeagnaceae, Ericaceae, Grossulariaceae, Loranthaceae, Pinaceae, Polygonaceae) 2 species each, and 15 family one species each.

Among 74 genera by content of species 11 genera standout (Fig. 2). 8 genera includes 3 species each and 13 genera - 2 species each. Greatest part of genera - 42 genera are presented by one species for each. So 55 genera, which make up $74.3 \%$ of whole composition of genera, are represented by only 1-2 species. Acorrdingly, floristic diversity is mostly conditioned by a great number of genera. It is noteworthy, that most of leading genera ( 7 genera) belong to Rosaceae family, that emprasizes one more time on the importance of this family in creation the dendroflora of Tbilisi area.

Composition of chorotypes (Types of geographic range). - We assign 166 species to 28 types of geographic range (chorotypes), which are united in 4 groups: boreal, Ancient Mediterranean, "conjunctive" and "widespread". Their proportions are given in Fig. 3.

Endemics. - One of the significant characteristic of any flora is endemism. High share of endemic species indicates to originality and uniqueness of flora. From 166 species of trees and shrubs spread in Tbilisi area 32 (19.3\%) are endemics of Caucasus. They are: Acantholimon lepturoides (Jaub. \& Spach) Boiss., Acer ibericum M. Bieb., Alnus glutinosa subsp. barbata (C. A. Mey.) Yalt., Astracantha caucasica (Pall.) Podlech, Astragalus tanae

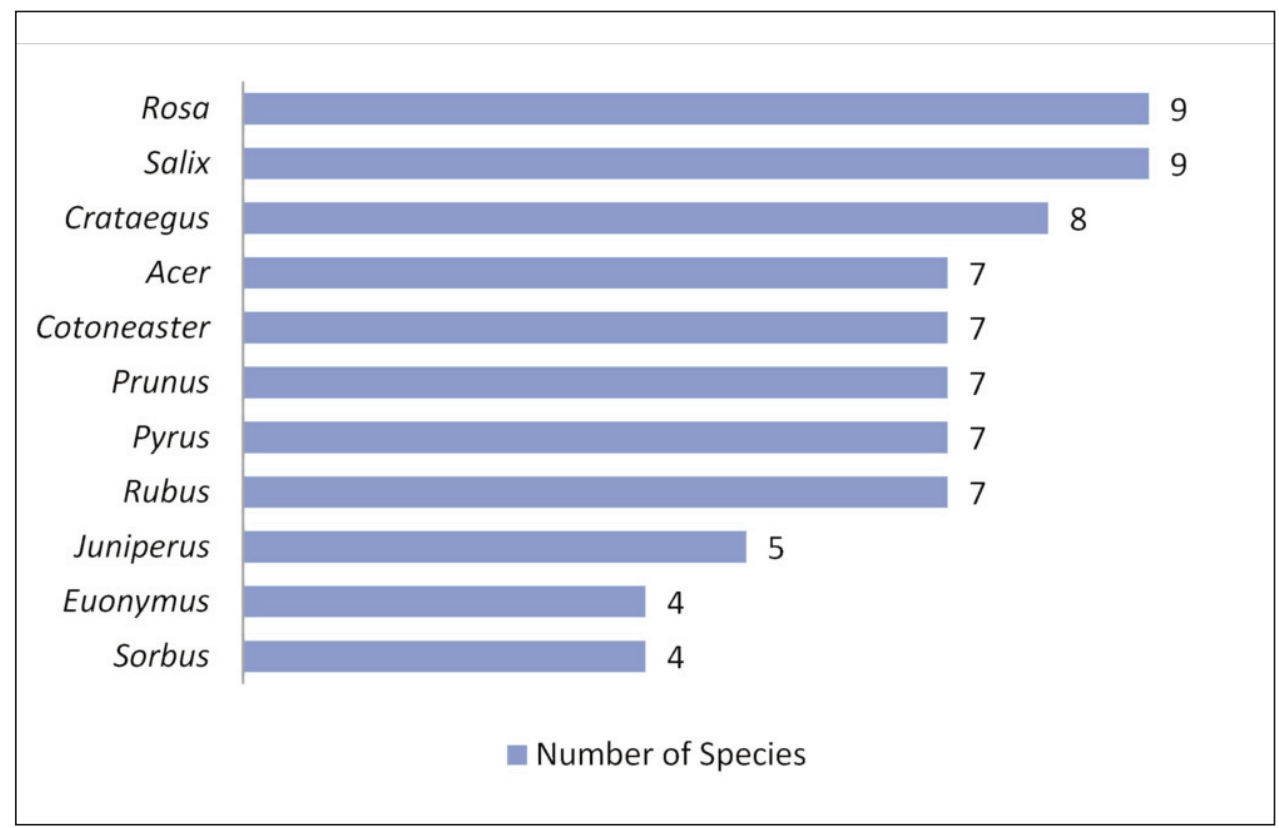

Fig. 2. Number of species by leading genera. 


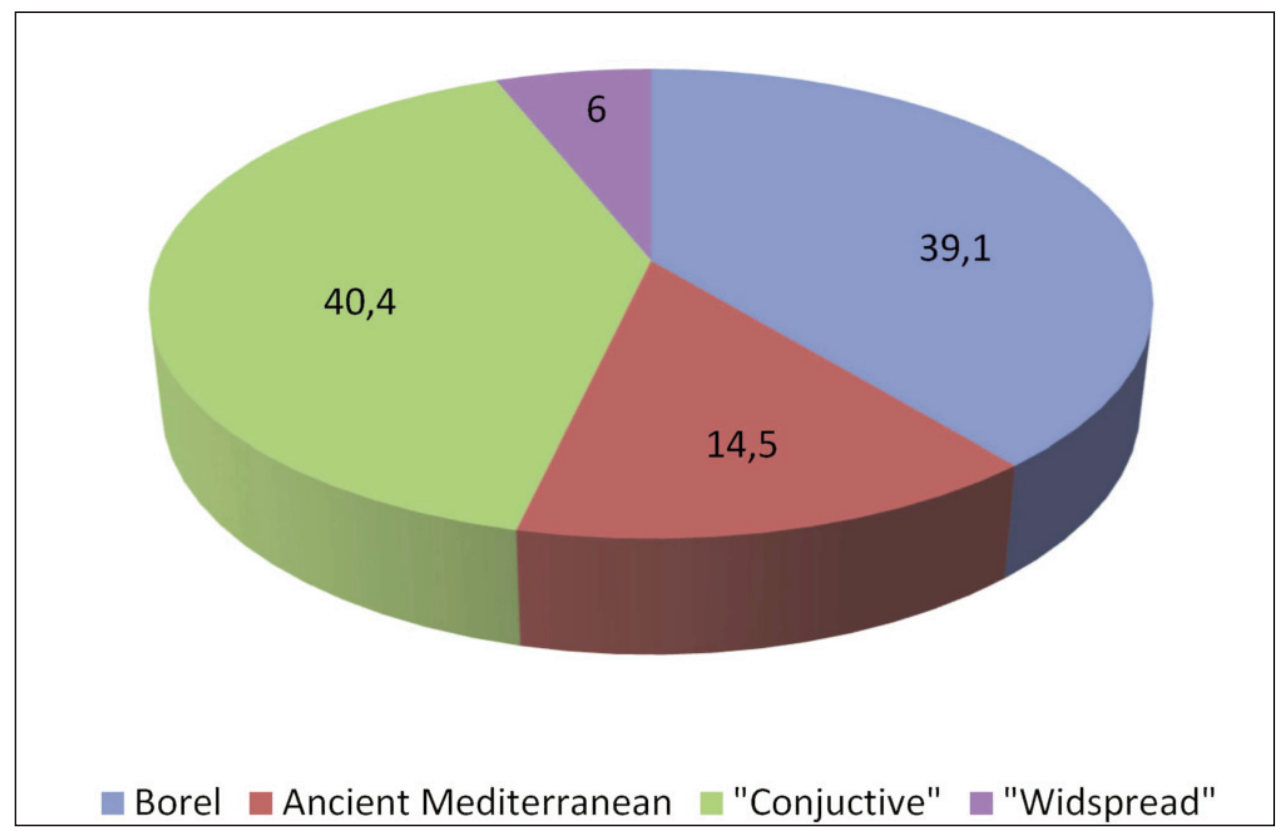

Fig. 3. Proportion (\%) of boreal, Ancient Mediterranean, "conjunctive" and "widespread" chorotypes.

Sosn., Berberis iberica DC., Cornus iberica Woronow, Corylus iberica Kem.-Nath., Cotoneaster meyeri Pojark., C. saxatilis Pojark., Crataegus caucasica K. Koch, Cytisus caucasicus Grossh., C. hirsutissimus K. Koch, Daphne axilliflora (Keissl.) Pobed., Daphne oleoides subsp. transcaucasica (Pobed.) Halda, Euonymus leiophloeus Steven, Philadelphus caucasicus Koehne, Picea orientalis (L.) Peterm., Prunus georgica (Desf.) Eisenman, Pyrus demetrii Kuth., P. fedorovii Kuth., P. georgica Kuth., P. ketzkhovelii Kuth., P. sachokiana Kuth., Rosa marschalliana Sosn., R. prilipkoana Sosn., R. transcaucasica Manden., Rubus caucasicus Focke, R. dolichocarpus Juz., R. ibericus Juz., Salix kuznetzowii Goerz, Sorbus caucasigena Gatsch..

Various botanical references (by instance, Makashvili 1952; Gviniashvili 1984; Gagnidze 2005; Solomon \& al. 2013; Lachashvili \& Eradze 2017; Davlianidze \& al. 2018) mentioned Swida armasica (Sanadze) Gvin. (Telycrania armasica Sanadze), which is local endemic of Tbilisi area. This species is not listed in international databases or is not discussed as accepted species. With that in mind, we have not included it in present article.

Relicts. - Relicts of the tertiary period deserve attention among the trees and shrubs of Tbilisi area. 13 relict species are distributed in Tbilisi area. They are: Buxus colchica Pojark., Corylus iberica Kem.-Nath., Fagus orientalis Lipsky, Hedera pastuchovii Woronow, Ilex colchica Pojark., Prunus laurocerasus L., Quercus macranthera Hohen., Quercus robur subsp. pedunculiflora (K. Koch) Menitsky, Smilax excelsa L., Staphylea pinnata L., Taxus baccata L., Vaccinium arctostaphylos L., Viburnum orientale Pall.. 


\section{Discussion}

Systematic structure. - Dominance of family Rosaceae which includes almost 1/3 of floristic composition is obvious. Such high share is completely regular, as Rosaceae is one of the characteristic families of the forests and, partly shrubberies. This family is always in the top ten families of nemoral, submediterranean and boreal floras (Turrill 1929; Tolmachev 1986; Chasapis \& al. 2020; Vladimirov \& al. 2020, etc.). Species diversity of the family Rosaceae considerably reduces from humid regions to the direction of semiarid and, especially arid regions (Tolmachev 1986; Lachashvili \& al. 2007; Lachashvili \& al. 2020). In the floristic spectrum of woody plants of Tbilisi area, diversity of this family is not expressed only in species diversity, but is represented by trees and shrubs of different bioecology which are spread in almost every ecosystem of Tbilisi area.

High location of Salicaceae in the floristic spectrum can be explained by diversity of species of genus Salix. 9 species from the 16 of the genus Salix common in Georgia (Davlianidze \& al. 2018) are presented in the area of Tbilisi. They are spread in various moist ravines. However, distribution area for most of them in Tbilisi area is limited and their importance in creation of main landscape is small. From this side, species of genus Populus (P. nigra, P. canescens) are more important.

Conversely other leading families, Fabaceae in dendroflora of Tbilisi area is not presented by characteristic species of forests and xeromesophilous shrubberies but xerophilous and hemixerophilous shrubs (Astracantha caucasica, A. microcephala, Astragalus tanae, A. cornutus, Caragana grandiflora, Colutea orientalis). They are characterstic species of tragacanthic, hemixerophilous shrubberies of shibliak type, xerophytic forests and rocks and scree-stones communities. Distributed Cytisus caucasicus and C. hirsutissimus besides them, which are less xerophilous comparing with the rest species and should be belonged to xeromesophilous plants.

Families Sapindaceae and Ulmaceae unites mesophilous species characterised for forests. Besides them xeromesophilous species are also (Celtis caucasica, C. planchoniana, Acer ibericum, Zelkova carpinifolia). Accordingly, their high position in the floristic spectrum is relevant.

Considering that, family Rhamnaceae unites woody plants its being in the top ten of the floristic spectrum is regular. In Tbilisi area, this family is represented by shrubs and trees with different bioecological. Parts of them (Paliurus spina-christi, Rhamnus pallasii, $R$. spathulifolia) are components of hemixerophilous shrubberies of shibliak type and xerophytic forests, growing in the rocks and scree-stones communities too, whereas Frangula alnus and Rhamnus cathartica are distributed in the forest edges, xeromesophilous shrubberies and partially in forests.

High position of Cupressaceae is due to the participation of Juniperus species (Juniperus communis, J. excelsa, J. foetidissima, J. oxycedrus, J. polycarpos), a characteristic genus of xerophitic forests. These species besides xerophitic forests are spread in hemixerophilous shrubberies and in the rocks and scree-stones communities. It is noteworthy, that J. communis is presented by 2 subspecies: J. communis subsp. hemisphaerica and J. communis subsp. oblonga. Noted subspecies are given according to Imkhanitskaya (2003). These subspecies by some researchers (Gagnidze 2005; Shetekauri \& Chelidze 2016; Davlianidze \& al. 2018) until now are discussed in the independent species rank (J. hemisphaerica C. Presl, J. oblonga M. Bieb.). 
Families Celastraceae, Cornaceae, Corylaceae, Fagaceae Oleaceae and Viburnaceae, which are presented by 4 species each mainly contains characteristic mesophilous trees and shrubs of forests and xeromesophilous shrubberies and their 8-13 position in floristic spectrum is natural. Moreover, main dominannts of forests (Quercus petraea subsp. iberica, Q. macranthera, Quercus robur subsp. pedunculiflora, Fagus orientalis, Fraxinus excelsior, F. angustifolia subsp. oxycarpa ) belong to Fagaceae and Oleaceae.

Chorotypes (Types of geographic range). - Boreal and "conjunctive" chorotypes are represented by nearly equal number of species.

Greatest number of species belongs to so-called "conjunctive chorotypes". Their total number consists of 67 species (40.4\%). In them, by capacity of species, European-Mediterranean, Euxino-Hyrcanian and Caucasian-South-West Asian chorotypes are distinguished.

Total number of boreal species are also big - 65 species (39.1\%). First of all this is conditioned by wide participation of Caucasian species - Caucasian chorotype contains almost the half of boreal plants. Here we will remark that part of researchers (Gagnidze 2004; Shetekauri \& Gagnidze 2000) Caucasian chorotype are considered within Ancient Mediterranean (in particular in submediterranean) region.

Comparing with "conjunctive" and boreal chorotypes, participation of Ancient Mediterranean species is small (24 species / 14.5\%). Widespread species are presented by the smallest amount (10 species / 6\%).

Among the chorotypes by content of species, Caucasian chorotype dominates (Table 2). It is important that 29 of Caucasian species are endemics of Caucasus and only 2 species have irradiation in South-West Asia [in particular to Anatolia (Pyrus caucasica) and NorthEast Iran (Rhamnus spathulifolia)]. Noteworthy that the species included in Caucasian chorotype are of different bioecology and belong to characteristic plants of various habitats. This emphasizes the highlighted role of this chorotype in creation of dendroflora of Tbilisi area.

In boreal chorotypes, after Caucasian, European-Caucasian chorotype is outstanding by its number of species. Not few number of these species points to the florogenetic connection with nemoral forests. These connections are firmed by the participation of EuroSiberian and European species. Influence of Euxine floristic center is also expressed.

Florogenetic connection of two directions is obvious in Ancient Mediterranean species: Mediterranean and South-West Asian. It is noteworthy, that the area of species connected to the Mediterranean mostly comprises East Mediterranean. Turanian-Central Asian connections are weakly impressed as well. It is significant, that the plants, of which area spread in both directions - on the one hand, Mediterranean and, on the other hand, SouthWest Asia, Turan, Central Asia, have an important place.

From the side of florogenetic connections, composition and ratio of "conjunctive" chorotypes is important and interesting. These chorotypes by distributed area can be divided into several groups: chorotypes connected with Europe and Mediterranean (EuropeanMediterranean, Submediterranean), chorotypes connected with Europe, Mediterranean and Soth-West Asia (European-Mediterranean-South-West Asian, European-MediterraneanSouth-West Asian-Central Asian), chorotypes connected with Caucasus and South-West Asia (Caucasian-South-West Asian, Caucasian-South-West Asian-Middle Asian, Caucasian-Anatolian and Caucasian-Middle Asian). Outstandingly, it is necessary to highlight the Euxino-Hyrcanian chorotype. First group emphasizes connections with 
Table 2. Proportion of chorotypes in the dendroflora of Tbilisi area.

\begin{tabular}{|c|c|c|c|c|}
\hline Chorotype & $\begin{array}{l}\text { Number of } \\
\text { species }\end{array}$ & $\%$ & $\begin{array}{l}\text { Number } \\
\text { of species }\end{array}$ & $\%$ \\
\hline Boreal species & & & & \\
\hline Caucasian & 31 & 18.7 & \multirow{7}{*}{65} & \multirow{7}{*}{39.1} \\
\hline European-Caucasian & 10 & 6.0 & & \\
\hline Eurasian steppe-Caucasian & 2 & 1.2 & & \\
\hline Caucasian-Euxinian & 1 & 0.6 & & \\
\hline European & 7 & 4.2 & & \\
\hline Euro-Siberian & 7 & 4.2 & & \\
\hline Euxinian & 7 & 4.2 & & \\
\hline \multicolumn{5}{|l|}{ Ancient Mediterranean species } \\
\hline Mediterranean & 6 & 3.6 & \multirow{8}{*}{24} & \multirow{8}{*}{14.5} \\
\hline Mediterranean-South-West Asian & 9 & 5.4 & & \\
\hline Mediterranean-South-West Asian-Turanian & 1 & 0.6 & & \\
\hline $\begin{array}{l}\text { Mediterranean-South-West Asian-Turanian-Central } \\
\text { Asian }\end{array}$ & 1 & 0.6 & & \\
\hline South-West Asian & 3 & 1.8 & & \\
\hline South-West Asian-Turanian & 1 & 0.6 & & \\
\hline South-West Asian-Turanian-Central Asian & 2 & 1.2 & & \\
\hline South-West Asian-Central Asian & 1 & 0.6 & & \\
\hline \multicolumn{5}{|l|}{ "Conjunctive" species } \\
\hline Submediterranean & 7 & 4.2 & \multirow{11}{*}{67} & \multirow{11}{*}{40.4} \\
\hline European-Mediterranean & 17 & 10.3 & & \\
\hline European-Mediterranean-South-West Asian & 5 & 3 & & \\
\hline $\begin{array}{l}\text { European-Mediterranean-South-West Asian-Central } \\
\text { Asian }\end{array}$ & 1 & 0.6 & & \\
\hline Euro-Siberian-Central Asian & 1 & 0.6 & & \\
\hline Euxino-Hyrcanian & 15 & 9.0 & & \\
\hline Caucasian-Hyrcanian & 1 & 0.6 & & \\
\hline Caucasian-South-West Asian & 14 & 8.4 & & \\
\hline Caucasian-South-West Asian-Middle Asian & 2 & 1.2 & & \\
\hline Caucasian-Anatolian & 3 & 1.8 & & \\
\hline Caucasian-Middle Asian & 1 & 0.6 & & \\
\hline \multicolumn{5}{|l|}{ Widespread species } \\
\hline Palearctic & 9 & 5.4 & 9 & \multirow{2}{*}{6.0} \\
\hline Holarctic & 1 & 0.6 & 1 & \\
\hline All & 166 & 100 & 166 & 100 \\
\hline
\end{tabular}

Remark - "Middle Asian" means mountainous Middle Asia (Pamir-Alay, Tian Shan, etc.).

nemoral forests. Simultaneously chorotypes of first group with chorotypes of second group strengthen the Mediterranean links. Chorotypes of second group play an important role in forming connection to South-West Asia direction and make conjunctive florogenetic bridge between Europe and South-West Asia. Chorotypes of the third group are distinguished: they make a kind of circle of florogenetic connection between Caucasus and South-West Asia. Most of species, which are united in these chorotypes, are hemixerophilous and xerophilous plants of dry ecotopes. Among the "conjunctive" chorotypes the species of Euxino-Hyrcanian chorotype deserve distinguished attention. Considering the location and peculiarity of physical-geographic conditions of Tbilisi area, their non-little 
share is completely regular. Euxinian and Hyrcanian ties strengthen also by CaucasianHyrcanian (Hedera pastuchovii) and Caucasian-Euxinian (Acer trautvetteri) plants.

In correspondence with "conjunctive" chorotypes, Holarctic species Juniperus communis is noteworthy. As noted, in Tbilisi area it is represented by two subspecies: Juniperus communis subsp. oblonga and Juniperus communis subsp. hemisphaerica. The first subspecies of them belongs to Caucasian-South-West Asian chorotype and the second subspecies we assign to Mediterranean-Caucasian chorotype. Participation of these subspecies also increases importance of "conjunctive" chorotypes in the structure of dendroflora of Tbilisi area.

Among widespread species plants of Palearctic chorotype are the main. 9 Palearctic species are distributed in 3 groups of geographic area: Palearctic - 3 species, South Palearctic - 2, West Palearctic - 4. Palearctic species belongs to plants of different bioecology and are spread in various habitats.

Presented data indicates different directions of florogenetic connections. Principal directions among them are: European (nemoral forests), Mediterranean, South-West Asian, Euxinian, Hircanian. Relatively weak ties are to direction Siberia. The links of Central Asia, Middle Asia and Turan are much weaker. In spite of many-sided florogenetic connections and powerful competition, role of local (Caucasian) species in forming of dendroflora of Tbilisi area are very high.

Endemic species. - By distributed area among endemic species 3 groups separate out:

Endemics of Caucasus (their distribution area covers both South and North Caucasus) - 16 species (Acer ibericum, Alnus glutinosa subsp. barbata, Astracantha caucasica, Cotoneaster meyeri, C.saxatilis, Crataegus caucasica, Cytisus caucasicus, C. hirsutissimus, Euonymus leiophloeus, Philadelphus caucasicus, Picea orientalis, Pyrus georgica, $P$. sachokiana, Rubus caucasicus, R. ibericus, Salix kuznetzowii);

Endemics of South Caucasus - 15 species (Acantholimon lepturoides, Prunus georgica, Astragalus tanae, Corylus iberica, Daphne axilliflora, D. oleoides subsp. transcaucasica, Pyrus demetrii, P. fedorovii, P. ketzkhovelii, Rosa marschalliana, $R$. prilipkoana, $R$. transcaucasica, Rubus dolichocarpus, Sorbus caucasigena, Cornus iberica);

Endemics of East Caucasus (their main distribution area is in the eastern part of Caucasus) - 1 species (Berberis iberica).

From endemic species 2 (Prunus georgica and Rosa transcaucasica) are endemics to Georgia.

32 Caucasus endemic species by chorotypes are distributed in this way: Caucasian chorotype - 29 species, Euxinian chorotype - 2 (Philadelphus caucasicus, Picea orientalis) and Euxinian-Hyrcanian - 1 (Alnus glutinosa subsp. barbata).

For territory which localed in crossing area of different floristic centres, $19.3 \%$ of endemism should be considered as high indicator.

Florogenetic connections of dendroflora by habitats. - As it was designated, in Tbilisi area trees and shrubs are spread in almost every habitat. Tendencies of florogenetic connections revealed in the principal habitats are discussed below.

In the dendroflora of forests most of all reveals boreal roots, especially ties with nemoral forests. Ancient Mediterranean connections are weakened - these links are reflected in the participating of species of "connective" chorotypes (Euxinian-Hyrcanian, EuropeanMediterranean, Submediterranean). 
In the dendroflora of hemixerophilous ecosistems (xerophitic forests, shrubberies of shibliak type, tragacanthic shrubberies, rocks and scree-stones communities) Ancient Mediterranean roots are expresed, whereas boreal links are weak. Boreal connections in many cases reveals in participation of plants of Caucasian and Caucasian-South-West Asian chorotypes. Participation of species linked with Europe is small. It is important, that Caucasian-South-West Asian species, in many cases, are plants of arid and semiarid regions. They, with their bioecological features and distribution area, have little in common with the boreal region. They, in our opinion, are more associated with Ancient Mediterranean ecosistems.

From the side of composition of chorotypes and florogenetic connections, between the forests and hemixerophilous ecosystems, the dendroflora of post-forest secondary xeromesophilous and mesoxerophilous shrubberies holds transitional condition. In these habitats trees and shrubs of different bioecology (hemixerophilous, mesophilous, xeromesophilous) are gathered. Consequently, species of both boreal, Ancient Mediterranean and "connective" chorotypes are widely presented. Accordingly, in the floristic composition there are reflected as boreal or Ancient Mediterranean ties. We face strong competition between these two floristic worlds, where the one side (boreal) fights for survival and the other (Ancient Mediterranean) expands its area.

An important role of "connective" species is highlighted in the dendroflora of almost every habitat.

It is also noteworthy that Caucaian species are seen in every habitat.

Received results put emphasis one more time on transitional character of flora of Tbilisi area and its originality.

Relicts. - Distributed area of relict trees and shrubs in Tbilisi area is limited. Most of the relicts are gathered on Saguramo-Ialno Ridge in moist environment and are the components of beech, elm beech-hornbeam and hornbeam forests. They are: Hedera pastuchovii, Vaccinium arctostaphylos, Viburnum orientale, Corylus iberica, Staphylea pinnata, Taxus baccata, Ilex colchica, Prunus laurocerasus and Buxus colchica. Corylus iberica and Staphylea pinnata are also spread on the east endings of Trialeti Ridge. Vaccinium arctostaphylos, Viburnum orientale, Ilex colchica and Prunus laurocerasus are components of Colchic forests, and Hedera pastuchovii is a characteristic species of Hyrcanian forests. We meet Quecus macranthera on the east endings of Trialeti Ridge. The relicts spread in the floodplain forests and moist ravines are: Quercus pedunculiflora and Smilax excelsa.

\section{General Conclusion}

The composition of chorotypes and ratio between them gives us opportunity to express the following point of view: geographic location of Tbilisi area in the intersection areal of various floristic centers, diversity of physical-geographic conditions and geological past gave an opportunity of spreading trees and shrubs of either boreal or South-West Asian and Mediterranean origin. On the one hand, invasion and settlement of mesophilous and on the other hand, hemixeropilous and xerophilous species was possible from various regions. Accordingly, forming of dendroflora of Tbilisi area was going through the "struggle" of boreal and Ancient Mediterranean floristic centers. Such competition in the intersection 
areal of various floristic centers conditioned wide assortment of "conjunctive" species. On the background of powerful competition, great number and different bioecological composition of local (Caucasian) species emphasize originality of flora of Tbilisi area. All that is stated above conditioned the complex character of dendroflora of Tbilisi area. We suppose that forming process of dendroflora of Tbilisi area was going on during a long period that not so small number of relict and endemic species speaks about.

Our expressed views based on chorotypes analysis reflect precisely transitional character of flora of Tbilisi area and are in complete concur with the view of M. Sakhokia (1961) about the fact, that Tbilisi area represent a kind of "botanical junction".

Floristic composition indicating chorotypes for each species in table form are given below (Table 3).

Table 3. Floristic composition of Tbilisi area dendroflora.

\begin{tabular}{|c|c|c|}
\hline \multicolumn{3}{|c|}{ GYMNOSPERMAE } \\
\hline Cupressaceae & $\begin{array}{l}\text { Juniperus communis L. } \\
\text { - } \quad \text { J. communis subsp. hemisphaerica (J. Presl \& } \\
\text { C. Presl (Hyman) (J. hemisphaerica C. Presl; J. } \\
\text { depressa Stevels) } \\
\text { - } \quad \text { J. communis subsp. oblonga (M. Bieb.) } \\
\text { Galushko (J. oblonga M. Bieb.; } \\
\text { J. communis var. saxatilis Pall.) } \\
\end{array}$ & $\begin{array}{ll}\text { Holarctic } \\
-\quad \text { Med.-Caucasian } \\
-\quad \text { Caucasian-S.-W. Asian } \\
\quad \text { (conditionally) }\end{array}$ \\
\hline & Juniperus excelsa M. Bieb. (J. isophyllos K. Koch) & $\begin{array}{l}\text { Med.-S.-W. Asian (E. } \\
\text { Med.-S.-W. Asian) }\end{array}$ \\
\hline & Juniperus foetidissima Willd. & Med. (E. Med.) \\
\hline & Juniperus oxycedrus L. (Juniperus rufescens Link) & Med. \\
\hline & Juniperus polycarpos K. Koch & S.-W. Asian \\
\hline Ephedraceae & $\begin{array}{l}\text { Ephedra major subsp. procera (C. A. Mey.) } \\
\text { Bornm. (E. procera C. A. Mey.) }\end{array}$ & $\begin{array}{l}\text { Med.-S.-W. Asian (E. } \\
\text { Med.-S.-W. Asian) }\end{array}$ \\
\hline Pinaceae & Picea orientalis (L.) Peterm. & $\begin{array}{l}\text { Euxinian (with irradiation) } \\
\text { (Cauc. endemic) }\end{array}$ \\
\hline & $\begin{array}{l}\text { Pinus sylvestris var. hamata Steven } \\
\text { [P. sylvestris var. hamata Steven; } P . \text { kochiana } \mathrm{K} . \\
\text { Koch; P. sosnowskyi Nakai] }\end{array}$ & $\begin{array}{l}\text { Caucasian-Anatolian (with } \\
\text { Crimean irradiation) }\end{array}$ \\
\hline Taxaceae & Taxus baccata $\mathrm{L}$. & European-Med. \\
\hline \multicolumn{3}{|c|}{ ANGIOSPERMAE } \\
\hline \multicolumn{3}{|c|}{ DYCOTYLEDONEAE } \\
\hline Anacardiaceae & Cotinus coggygria Scop. & Palearctic (S. Palearctic) \\
\hline & $\begin{array}{l}\text { Pistacia atlantica subsp. mutica (Fisch. \& C. A. } \\
\text { Mey.) Rech. f. (Pistacia mutica Fisch \& C. A. } \\
\text { Mey.) }\end{array}$ & Med.-S.-W. Asian \\
\hline & Rhus coriaria L. & Med.-S.-W. Asian \\
\hline $\begin{array}{l}\text { Apocynaceae } \\
\text { (Asclepiadaceae) }\end{array}$ & Periploca graeca L. & $\begin{array}{l}\text { Euxino-Hyrcanian (with E. } \\
\text { Med. irradiation) }\end{array}$ \\
\hline Aquifoliaceae & Ilex colchica Pojark. & $\begin{array}{l}\text { Euxinian (Colchic, Colchic- } \\
\text { Lazistanian) }\end{array}$ \\
\hline Araliaceae & Hedera helix $\mathrm{L}$. & European-Med. \\
\hline & Hedera pastuchovii Woronow & $\begin{array}{l}\text { Caucasian-Hyrcanian (E. } \\
\text { Caucasian-Hyrcanian) }\end{array}$ \\
\hline Berberidaceae & Berberis iberica DC. & Caucasian (Cauc. endemic) \\
\hline & Berberis vulgaris L. & European-Med. \\
\hline
\end{tabular}


Table 3. continued.

\begin{tabular}{|c|c|c|}
\hline Betulaceae & $\begin{array}{l}\text { Alnus glutinosa subsp. barbata (C. A. Mey.) Yalt. } \\
\text { (A. barbata C. A. Mey.) }\end{array}$ & $\begin{array}{l}\text { Euxino-Hyrcanian (Cauc. } \\
\text { endemic) }\end{array}$ \\
\hline & Betula litwinowii Doluch. & Euxino-Hyrcanian \\
\hline & Betula pendula Roth & Euro-Siberian \\
\hline Buxaceae & Buxus colchica Pojark. & Euxinian (Colchic) \\
\hline \multirow[t]{3}{*}{ Caprifoliaceae } & Lonicera caprifolium $\mathrm{L}$. & $\begin{array}{l}\text { European-Med. (C. } \\
\text { European-Med.) }\end{array}$ \\
\hline & Lonicera caucasica Pall. & Caucasian-S.-W. Asian \\
\hline & Lonicera iberica M. Bieb. & Caucasian-S.-W. Asian \\
\hline \multirow{4}{*}{ Celastraceae } & Euonymus europaeus L. & European-Caucasian \\
\hline & Euonymus latifolius (L.) Mill. & Submed. \\
\hline & Euonymus leiophloeus Steven & Caucasian (Cauc. endemic) \\
\hline & Euonymus verrucosus Scop. & European-Caucasian \\
\hline Cistaceae & Fumana procumbens (Dunal) Gren. \& Godr. & $\begin{array}{l}\text { European-Med. (C. } \\
\text { European-Med.) }\end{array}$ \\
\hline \multirow[t]{3}{*}{ Cornaceae } & $\begin{array}{l}\text { Cornus iberica Woronow [Swida iberica } \\
\text { (Woronow) Grossh.] }\end{array}$ & Caucasian (Cauc. endemic) \\
\hline & Cornus mas L. & Submed. \\
\hline & $\begin{array}{l}\text { Cornus sanguinea subsp. australis (C. A. Mey.) } \\
\text { Jáv. [C. australis C. A. Mey.; Swida australis (C. } \\
\text { A. Mey.) Grossh.] }\end{array}$ & $\begin{array}{l}\text { European-Caucasian } \\
\text { (conditionally) }\end{array}$ \\
\hline \multirow[t]{4}{*}{ Corylaceae } & Carpinus betulus L. (C. caucasica Grossh.) & European-Caucasian \\
\hline & Carpinus orientalis Mill. & Submed. (E. Submed.) \\
\hline & Corylus avellana $\mathrm{L}$. & European-Caucasian \\
\hline & Corylus iberica Kem.-Nath. & Caucasian (Cauc. endemic) \\
\hline \multirow[t]{2}{*}{ Elaeagnaceae } & Elaeagnus angustifolia $\mathrm{L}$. & Palearctic (S. Palearctic) \\
\hline & Hippophaë rhamnoides $\mathrm{L}$ & $\begin{array}{l}\text { European-Med.-S.-W. } \\
\text { Asian-C. Asian }\end{array}$ \\
\hline \multirow[t]{2}{*}{ Ericaceae } & Rhododendron luteum Sweet & $\begin{array}{l}\text { Euxinian (with European } \\
\text { irradiation) }\end{array}$ \\
\hline & Vaccinium arctostaphylos L. & Euxino-Hyrcanian \\
\hline \multirow[t]{8}{*}{ Fabaceae } & Astracantha caucasica (Pall.) Podlech & Caucasian (Cauc. endemic) \\
\hline & Astracantha microcephala (Willd.) Podlech & $\begin{array}{l}\text { Caucasian-S.-W. Asian (S. } \\
\text { Caucasian-S.-W. Asian) }\end{array}$ \\
\hline & Astragalus cornutus Pall. & $\begin{array}{l}\text { Eurasian steppe-Caucasian } \\
\text { (with Iranian irradiation) }\end{array}$ \\
\hline & Astragalus tanae Sosn. & Caucasian (Cauc. endemic) \\
\hline & Caragana grandiflora (M. Bieb.) DC. & Caucasian-S.-W. Asian \\
\hline & Colutea orientalis Mill. & $\begin{array}{l}\text { Med. (E. Med.; Caucasian- } \\
\text { Crymean) }\end{array}$ \\
\hline & $\begin{array}{l}\text { Cytisus caucasicus Grossh. [Chamaecytisus } \\
\text { caucasicus (Grossh.) Holub] }\end{array}$ & Caucasian (Cauc. endemic) \\
\hline & Cytisus hirsutissimus K. Koch & Caucasian (Cauc. endemic) \\
\hline \multirow[t]{4}{*}{ Fagaceae } & Fagus orientalis Lipsky & Euxino-Hyrcanian \\
\hline & $\begin{array}{l}\text { Quercus macranthera Fisch. \& C. A. Mey. ex } \\
\text { Hohen. }\end{array}$ & Caucasian-S.-W. Asian \\
\hline & $\begin{array}{l}\text { Quercus petraea subsp. iberica (M. Bieb.) Krassiln. } \\
\text { (Q. iberica M. Bieb.) }\end{array}$ & Caucasian-S.-W. Asian \\
\hline & $\begin{array}{l}\text { Quercus robur subsp. pedunculiflora }(\mathrm{K} . \text { Koch) } \\
\text { Menitsky (Q. pedunculiflora K. Koch) }\end{array}$ & Med. (E. Med.) \\
\hline \multirow[t]{2}{*}{ Grossulariaceae } & Ribes alpinum L. & European \\
\hline & $\begin{array}{l}\text { Ribes uva-crispa L. [Grossularia reclinata (L.) } \\
\text { Mill.; R. reclinatum L.] }\end{array}$ & European \\
\hline
\end{tabular}


Table 3. continued.

\begin{tabular}{|c|c|c|}
\hline Hydrangeaceae & Philadelphus caucasicus Koehne & $\begin{array}{l}\text { Euxinian (with irradiation) } \\
\text { (Cauc. endemic) }\end{array}$ \\
\hline \multirow{2}{*}{$\begin{array}{l}\text { Loranthaceae } \\
\text { (Santalaceae, } \\
\text { Viscaceae) } \\
\end{array}$} & Arceuthobium oxycedri (DC.) M. Bieb. & Med.-S.-W. Asian \\
\hline & Viscum album $\mathrm{L}$. & Palearctic (conditionally) \\
\hline $\begin{array}{l}\text { Malvaceae } \\
\text { (Tiliaceae) }\end{array}$ & Tilia begoniifolia Steven & Euxino-Hyrcanian \\
\hline Moraceae & Ficus carica L. & S.-W. Asian \\
\hline \multirow[t]{4}{*}{ Oleaceae } & Fraxinus excelsior $\mathrm{L}$. & European-Caucasian \\
\hline & $\begin{array}{l}\text { Fraxinus angustifolia subsp. oxycarpa (Willd.) } \\
\text { Franco \& Rocha Afonso (F. oxycarpa Willd.) }\end{array}$ & $\begin{array}{l}\text { Submed. (E. Submed.) } \\
\text { (conditionally) }\end{array}$ \\
\hline & Jasminum fruticans $\mathrm{L}$. & $\begin{array}{l}\text { European-Med.-S.-W. } \\
\text { Asian }\end{array}$ \\
\hline & Ligustrum vulgare L. & European-Med. \\
\hline Plumbaginaceae & Acantholimon lepturoides (Jaub. \& Spach) Boiss. & Caucasian (endemic) \\
\hline \multirow[t]{2}{*}{ Polygonaceae } & Atraphaxis caucasica (Hoffm.) Pavlov & Caucasian-M. Asian \\
\hline & Atraphaxis spinosa $\mathrm{L}$. & $\begin{array}{l}\text { Med.-S.-W. Asian- } \\
\text { Turanian-C. Asian (E. } \\
\text { Med.-S.-W. Asian- } \\
\text { Turanian-Jungaro- } \\
\text { Kashgarian) }\end{array}$ \\
\hline Ranunculaceae & Clematis vitalba $\mathrm{L}$. & European-Med. \\
\hline \multirow{5}{*}{ Rhamnaceae } & Frangula alnus Mill. & Euro-Siberian \\
\hline & Paliurus spina-christi Mill. & Med.-S.-W. Asian \\
\hline & Rhamnus cathartica $\mathrm{L}$. & Palearctic \\
\hline & Rhamnus pallasii Fisch. \& C. A. Mey. & Caucasian-S.-W. Asian \\
\hline & Rhamnus spathulifolia Fisch. \& C. A. Mey. & Caucasian \\
\hline \multirow[t]{18}{*}{ Rosaceae } & Amelanchier ovalis Medic. & $\begin{array}{l}\text { European-Med. (C. } \\
\text { European-Med.) }\end{array}$ \\
\hline & Cotoneaster integerrimus Medic. & $\begin{array}{l}\text { European-Med.-S.-W. } \\
\text { Asian (conditionally) }\end{array}$ \\
\hline & Cotoneaster melanocarpus Fisch. ex A. Blytt. & Euro-Siberian-C. Asian \\
\hline & Cotoneaster meyeri Pojark. & Caucasian (endemic) \\
\hline & Cotoneaster morulus Pojark. & Caucasian-S.-W. Asian \\
\hline & Cotoneaster racemiflorus (Desf.) K. Koch & $\begin{array}{l}\text { Caucasian-S.-W. Asian-M. } \\
\text { Asian }\end{array}$ \\
\hline & Cotoneaster saxatilis Pojark. & Caucasian (endemic) \\
\hline & Cotoneaster suavis Pojark. & $\begin{array}{l}\text { S.-W. Asian-C. Asian } \\
\text { (conditionally) }\end{array}$ \\
\hline & Crataegus caucasica K. Koch & Caucasian (endemic) \\
\hline & Crataegus kyrtostyla Fingerh. & $\begin{array}{l}\text { European-Caucasian } \\
\text { (condotionally) }\end{array}$ \\
\hline & Crataegus meyeri Pojark. & Caucasian-S.-W. Asian \\
\hline & Crataegus microphylla K. Koch & Euxino-Hyrcanian \\
\hline & Crataegus orientalis M. Bieb. & Med. (E. Med.) \\
\hline & Crataegus pentagyna Willd. & Euxino-Hyrcanian \\
\hline & $\begin{array}{l}\text { Crataegus pontica K. Koch [C. azarolus var. } \\
\text { pontica (K. Koh) K. I. Chr.] }\end{array}$ & S.-W. Asian \\
\hline & Crateagus pseudoheterophylla Pojark. & Caucasian-S.-W. Asian \\
\hline & $\begin{array}{l}\text { Malus orientalis Uglitzk. [M. sylvestris subsp. } \\
\text { orientalis (Uglitzk.) Browicz] }\end{array}$ & Caucasian-S.-W. Asian \\
\hline & Mespilus germanica $\mathrm{L}$. & Euxino-Hyrcanian \\
\hline
\end{tabular}


Table 3. continued.

\begin{tabular}{|c|c|c|}
\hline & $\begin{array}{l}\text { Prunus avium (L.) L. [Cerasus avium (L.) Moench; } \\
\text { C. silvestris Garsault] }\end{array}$ & European-Med. \\
\hline & Prunus divaricata Ledeb. & $\begin{array}{l}\text { Med.-S.-W. Asian (E. } \\
\text { Med.-S.-W. Asian) }\end{array}$ \\
\hline & $\begin{array}{l}\text { Prunus georgica (Desf.) Eisenman (Amygdalus } \\
\text { georgica Desf.) }\end{array}$ & Caucasian (endemic) \\
\hline & $\begin{array}{l}\text { Prunus incana (Pall.) Batsch [Cerasus incana } \\
\text { (Pall.) Spach] }\end{array}$ & Caucasian-S.-W. Asian \\
\hline & $\begin{array}{l}\text { Prunus laurocerasus L. (Laurocerasus officinalis } \\
\text { M. Roem.) }\end{array}$ & Euxino-Hyrcanian \\
\hline & $\begin{array}{l}\text { Prunus mahaleb L. [Cerasus mahaleb (L.) Mill.; } \\
\text { Padellus mahaleb (L.) Vassilcz.] }\end{array}$ & $\begin{array}{l}\text { European-Med.-S.-W. } \\
\text { Asian }\end{array}$ \\
\hline & Prunus spinosa $\mathrm{L}$. & European-Med. \\
\hline & Pyracantha coccinea M. Roem. & Euxino-Hyrcanian \\
\hline & $\begin{array}{l}\text { Pyrus caucasica Fed. [Pyrus communis subsp. } \\
\text { caucasica (Fed.) Browicz] }\end{array}$ & Caucasian \\
\hline & Pyrus demetrii Kuth. & Caucasian (endemic) \\
\hline & Pyrus fedorovii Kuth. & Caucasian (endemic) \\
\hline & Pyrus georgica Kuth. & Caucasian (endemic) \\
\hline & Pyrus ketzkhovelii Kuth. & Caucasian (endemic) \\
\hline & Pyrus sachokiana Kuth. & Caucasian (endemic) \\
\hline & Pyrus salicifolia Pall. & Caucasian-S.-W. Asian \\
\hline & Rosa canina $\mathrm{L}$. & $\begin{array}{l}\text { European-Med.-S.-W. } \\
\text { Asian }\end{array}$ \\
\hline & Rosa corymbifera Borkh. & $\begin{array}{l}\text { European-Med.-S.-W. } \\
\text { Asian }\end{array}$ \\
\hline & Rosa marschalliana Sosn. & Caucasian (endemic) \\
\hline & Rosa micrantha Borrer ex Sm. & European-Med. \\
\hline & Rosa mollis $\mathrm{Sm}$. & European \\
\hline & Rosa prilipkoana Sosn. & Caucasian (endemic) \\
\hline & Rosa spinosissima $\mathrm{L}$. & Palearctic (W. Palearctic) \\
\hline & Rosa transcaucasica Manden. & Caucasian (endemic) \\
\hline & Rosa tomentosa Sm. & European \\
\hline & Rubus anatolicus Focke & $\begin{array}{l}\text { Med.-S.-W. Asian (E. } \\
\text { Med.-S.-W. Asian) }\end{array}$ \\
\hline & Rubus caesius $\mathrm{L}$. & Palearctic (W. Palearctic) \\
\hline & Rubus caucasicus Focke & Caucasian (endemic) \\
\hline & Rubus dolichocarpus Juz. & Caucasian (endemic) \\
\hline & Rubus hirtus Waldst. \& Kit. & European-Caucasian \\
\hline & Rubus ibericus Juz. & Caucasian (endemic) \\
\hline & Rubus idaeus $\mathrm{L}$. & $\begin{array}{l}\text { Euro-Siberian (Euro-W. } \\
\text { Siberian) }\end{array}$ \\
\hline & Sorbus caucasigena Gatsch. & Caucasian (endemic) \\
\hline & Sorbus graeca (Spach) S. Schauer & $\begin{array}{l}\text { European-Med. (C. } \\
\text { European-Med.) }\end{array}$ \\
\hline & Sorbus torminalis (L.) Crantz & European-Med. \\
\hline & Sorbus turcica Zinserl. & $\begin{array}{l}\text { Med. (E. Med.) } \\
\text { (conditionally) }\end{array}$ \\
\hline & Spiraea hypericifolia L. & Eurasian steppe-Caucasian \\
\hline Salicaceae & Populus canescens (Aiton) Sm. & European (with irradiation) \\
\hline & Populus nigra L. & Palearctic (W. Palearctic) \\
\hline & \begin{tabular}{|l} 
Populus tremula $\mathrm{L}$. \\
Popula
\end{tabular} & Euro-Siberian \\
\hline & Salix alba L. & Palearctic (W. Palearctic) \\
\hline
\end{tabular}


Table 3. continued.

\begin{tabular}{|c|c|c|}
\hline & Salix caprea $\mathrm{L}$ & Euro-Siberian \\
\hline & Salix elbursensis Boiss. & Caucasian-S.-W. Asian \\
\hline & Salix excelsa S.G.Gmel. & S.-W. Asian-Turanian \\
\hline & Salix kuznetzowii Goerz & Caucasian (endemic) \\
\hline & Salix micans Andersson & Caucasian-Anatolian \\
\hline & Salix pseudomedemii E. L. Wolf & Caucasian-Anatolian \\
\hline & Salix triandra L. & Euro-Siberian \\
\hline & Salix wilhelmsiana $\mathrm{M}$. Bieb. & $\begin{array}{l}\text { Irano-Turanian-C. Asian } \\
\text { (Irano-Turanian-Jungaro-- } \\
\text { Kashgarian) }\end{array}$ \\
\hline \multirow[t]{7}{*}{$\begin{array}{l}\text { Sapindaceae } \\
\text { (Aceraceae) }\end{array}$} & Acer campestre $\mathrm{L}$. & European-Caucasian \\
\hline & Acer cappadocicum Gled. (A. laetum C. A. Mey.) & Euxino-Hyrcanian \\
\hline & Acer hyrcanum Fisch. \& C. A. Mey. & Euxino-Hyrcanian \\
\hline & $\begin{array}{l}\text { Acer ibericum M. Bieb. [A. } \\
\text { monspessulanum subsp. ibericum (M. Bieb. ex } \\
\text { Willd.) Yalt.] }\end{array}$ & Caucasian (endemic) \\
\hline & Acer platanoides $\mathrm{L}$. & European-Caucasian \\
\hline & Acer pseudoplatanus $\mathrm{L}$. & European (C. European) \\
\hline & $\begin{array}{l}\text { Acer trautvetteri Medv. [A. heldreichii subsp. } \\
\text { trautvetteri (Medw.) A. E. Murray] }\end{array}$ & Caucasian-Euxinian \\
\hline Staphyleaceae & Staphylea pinnata $\mathrm{L}$. & Submed. \\
\hline \multirow[t]{3}{*}{ Tamaricaceae } & Myricaria germanica (L.) Desv. & Palearctic \\
\hline & Tamarix ramosissima Ledeb. & $\begin{array}{l}\text { S.-W. Asian-Turanian-C. } \\
\text { Asian (Irano-Turanian-C. } \\
\text { Asian) }\end{array}$ \\
\hline & $\begin{array}{l}\text { Tamarix smyrnensis Bunge (T. hohenackeri } \\
\text { Bunge) }\end{array}$ & $\begin{array}{l}\text { Med.-S.-W. Asian-- } \\
\text { Turranian (E. Med.-S.-W. } \\
\text { Asian-Turanian) }\end{array}$ \\
\hline \multirow[t]{3}{*}{ Thymelaeaceae } & $\begin{array}{l}\text { Daphne axilliflora (Keissl.) Pobed. [D. caucasica } \\
\text { subsp. axilliflora (Keissl.) Halda] }\end{array}$ & Caucasian (endemic) \\
\hline & Daphne pontica L. & Euxinian (with irradiations) \\
\hline & $\begin{array}{l}\text { Daphne oleoides subsp. transcaucasica (Pobed.) } \\
\text { Halda (D. transcaucasica Pobed.) }\end{array}$ & Caucasian (endemic) \\
\hline \multirow[t]{6}{*}{ Ulmaceae } & $\begin{array}{l}\text { Celtis australis subsp. caucasica (Willd.) } \\
\text { C.C. Towns. (C. caucasica Willd.) }\end{array}$ & $\begin{array}{l}\text { Caucasian-S.-W. Asian-M. } \\
\text { Asian (S. Caucasian-S.-W. } \\
\text { Asian-M. Asian) }\end{array}$ \\
\hline & $\begin{array}{l}\text { Celtis planchoniana K. I. Chr. (C. glabrata Steven } \\
\text { ex Planch., nom. illeg.) }\end{array}$ & Submed. (E. Submed.) \\
\hline & Ulmus elliptica K. Koch & European-Caucasian \\
\hline & Ulmus glabra Huds. & European \\
\hline & Ulmus minor Mill. & European-Med. \\
\hline & Zelkova carpinifolia (Pall.) K. Koch & Euxino-Hyrcanian \\
\hline \multirow[t]{4}{*}{ Viburnaceae } & Sambucus nigra $\mathrm{L}$. & European-Med. \\
\hline & Viburnum lantana $\mathrm{L}$. & $\begin{array}{l}\text { European-Med. (C. } \\
\text { European-Med.) }\end{array}$ \\
\hline & Viburnum opulus L. & $\begin{array}{l}\text { Euro-Siberian (Euro-W. } \\
\text { Siberian) }\end{array}$ \\
\hline & Viburnum orientale Pall. & Euxinian (with irradiation) \\
\hline Vitaceae & $\begin{array}{l}\text { Vitis sylvestris C. C. Gmel. [V. vinifera } \\
\text { subsp. sylvestris (C. C. Gmel.) Hegi] }\end{array}$ & Med.-S.-W. Asian \\
\hline \multicolumn{3}{|c|}{ MONOCOTYLEDONEAE } \\
\hline $\begin{array}{l}\text { Asparagaceae } \\
\text { (Ruscaceae) }\end{array}$ & $\begin{array}{l}\text { Ruscus aculeatus L. [R. ponticus Woronow; } R \text {. } \\
\text { aculeatus subsp. ponticus (Woronow) Gagnidze] }\end{array}$ & European-Med. \\
\hline Smilacacea & Smilax excelsa $\mathrm{L}$. & Euxino-Hyrcanian \\
\hline
\end{tabular}


Abreviations: C. - Central, Cauc. - Caucasus, E. - East, M. - Middle, N. - North, S. - South, W. West.; Med. - Mediterranean, Submed. - Submediterranean.

\section{Acknowledgements}

We thank Mrs. Nutsa Meghvinetukhutsesi and Dr. Giorgi Mikeladze for mapping.

\section{References}

Browicz, K. 1989: Chorology of the Euxinian and Hyrcanian element in the woody flora of Asia. Pp. 305- 314 in: Ehrendofer, F. (ed.), Woody Plants - Evolution and distribution since the Tertiary. - Wien.

Chasapis, M., Samaras, D. A., Theodoropoulos, K. \& Eleftheriadou, E. 2020: The vascular flora of Mt Tzena (northern Greece). - Fl. Medit. 30: 55-63. https://doi.org/10.7320/FlMedit30.055

Davlianidze, M., Gviniashvili, Ts., Mukbaniani, M., Jinjolia-Imnadze, L. \& Jugheli, T. 2018: Nomenclatural checklist of flora of Georgia. - Tbilisi.

Euro+Med 2006+ [continuously updated]: Euro+Med PlantBase - the information resource for EuroMediterranean plant diversity. - http://www.europlusmed.org [Last accessed 10/04/2201].

Gagnidze, R. 2004: Up to date problems and tasks of botanical geography of the Caucasus. - Not. Syst. Geogr. Inst. Bot. Thbilissiensis 44-45: 8-52 [in Russian].

- 2005: Vascular plants of Georgia. A nomenclatural checklist. - Tbilisi.

— \& Davitadze, M. 2000: Adgilobrivi flora. - Batumi [in Georgian].

GBIF.org 2021: GBIF Home Page. - https://www.gbif.org [Last accessed 10/04/2021].

Gviniashvili Ts., 1984: Cornaceae Link. - Pp. 326-333 in: Ketskhoveli, N. (Ed.-in-Chief), Sakartvelos flora, 9. - Tbilisi [in Georgian].

Imkhanitskaya, N. N. 2003: Cupressaceae S.F. Gray - Pp. 179-185 in: Takhtajan, A. L. (Ed.-inChief), Caucasian flora conspectus, 1. - Saint-Petersburg [in Russian].

IPNI 2021: International Plant Names Index. - http://www.ipni.org [Last accessed 10/4/2021].

Ivanishvili, M. A. 1973: Flora formatsii kolucheastragalovykh tragakantnikov severnogo sklona Bol'shogo Kavkaza. - Tbilisi [in Russian].

Kavrishvili, K. V. 1964: Fiziko-geograficheskaya kharkteristika okrestnostei Tbilisi. - Tbilisi [in Russian].

Lachashvili J., Lachashvili N., Khachidze M. 2007: Conspectus of flora of Kiziki (East Georgia). - Tbilisi.

Lachashvili, N. J., Eradze, N. V. \& Khetsuriani L. D. 2017: Conspectus of trees and shrubs of Tbilisi environs (East Georgia, South Caucasus). - J. Ann. Agrar. Sci. 15(1): 118-129. https://doi.org/10.1016/j.aasci.2016.08.008

- , - \& - 2020: Floristic composition of pistachio-woodland (Pistacieta atlantici) of Georgia (South Caucasus). - Fl. Medit. 30: 39-53. https://doi.org/10.7320/FlMedit30.039

—, Khachidze M. N., Khetsuriani, L. D. \& Eradze, N. V. 2013: Typology and distribution regularities of the vegetation of Tbilisi environs (East Georgia, South Caucasus). - J. Ann. Agrar. Sci. 13(3): $55-62$.

Makashvili, A. 1952: Tbilisis midamoebis flora, 1. - Tbilisi [in Georgian].

- 1953: Flora of Tbilisi Environs, 2. - Tbilisi [in Georgian].

Maruashvili, M. 1964: Sakartvelos fizikuri geografia. - Tbilisi [in Georgian].

Meusel, H. \& Jäger, E. J. 1989: Ecogeographical differentiation of the Submediterranean deciduous forest flora. - Pp. 315-329 in: F. Ehrendofer (ed.), Woody Plants - Evolution and distribution since the Tertiary. - Wien. 
Portenier, N. N. 2000a: Methodical aspects of the elaboration of geographical elements in Caucasian flora. - Bot. J. 85(6): 76-84 [in Russian].

— 2000b: A system of geographical elements of the Caucasian flora. - Bot. J. 85(9): 26-33 [in Russian].

Sakhokia, M. F. 1961: Botanical description of the environs of Tbilisi and of the route from Tbilisi to the Shiraki plateau. - Pp. 7-25 in: Sakhokia, M. F. (ed.), Botanical Excursions over Georgia. - Tbilisi.

Shetekauri, Sh. \& Gagnidze, R. 2000: Diversity of high-mountain endemic flora of the Greater Caucasus. - Pp. 151-158 in: Beruchashvili, N., Kushlin, A. \& Zazanashvili, N. (eds), Biological and landscape diversity of Georgia. - Tbilisi.

— \& Chelidze, D. 2016: High mountain flora of Meskheti and Javakheti (Lesser Caucasus). -Tbilisi [in Georgian].

Solomon, J., Shulkina, T. \& Schatz, G. E. (eds) 2013: Red list of the endemic plants of the Caucasus: Armenia, Azerbaijan, Georgia, Iran, Russia and Turkey. Monographs in systematic botany from the Missouri Botanical Garden (MSB) 125. - Saint Louis.

Takhtajan A. L. 1978: The Floristic regions of the World. - Leningrad [in Russian].

Tatashidze, Z. 2000: Tbilisi. - Pp. 200-207 in: Tatashidze, Z. (ed.), Sakartvelos Geografia, 1. Tbilisi [in Georgian].

The Plant List 2021: Version 1.1. - http://www.theplantlist.org/ [Last accessed 10/04/2021].

Tolmachev, A. I. 1986: Metody sravnitelnoi floristiki i problemy florogeneza. - Novosibirsk [in Russian].

Tropicos.org. Missouri Botanical Garden. - http://www.tropicos.org [Last accessed 10/04/2021].

Turrill, W. B. 1929: The plant life of the Balkan Peninsula. - Oxford.

Ukleba, D. 1968: Aghmosavlet Sakartvelos fizikur-geografiuli daraioneba. - Tbilisi [in Georgian].

- 1974: Aghmosavlet Sakartvelos mtiani mkhareebis landshaftebi da fizikur-geografiuli raionebi. Tbilisi [in Georgian].

Urushadze, T. (ed.) 1999: Soil Map of Georgia. - Tbilisi.

- 2016: Soils of Georgia. - Tbilisi.

Vladimirov V., Bancheva S., Delcheva M., Vassilev K. \& Pedashenko H. 2020: Contribution to the knowledge of habitat and vascular plant diversity of Alibotush Reserve, Slavyanka Mountain (Bulgaria). - Fl. Medit. 30: 19-32. https://doi.org/10.7320/FlMedit30.019

Addresses of the authors:

Nikoloz Lachashvili ${ }^{1 *}$, Nino Eradze ${ }^{2} \&$ Konstantine Kereselidze ${ }^{3}$,

${ }^{1}$ National Botanical Garden of Georgia; Ilia State University, Institute of Botany. 1, Botanikuri Str., Tbilisi, 0105, Georgia. E-mails: lachashvili@gmail.com, nikoloz.lachashvili@iliauni.edu.ge

${ }^{2}$ National Botanical Garden of Georgia. 1, Botanikuri Str., Tbilisi, 0105, Georgia. Email: ninia.eredze@gmail.com

${ }^{3}$ Ilia State University, Institute of Botany. 1, Botanikuri Str., Tbilisi, 0105, Georgia. E-mails: konstantine.kereselidze.1@iliauni.edu.ge; kostabox@gmail.com

*Corresponding author. 